\title{
Development of handloom shawls from pure and blended yarns of mulberry silk and merino wool
}

Alka Goel and Hema Upadhayay

Received: 28.12.2017; Revised: 11.04.2018; Accepted: 30.04.2018

See end of the paper for authors' affiliations

Alka Goel

Department of Clothing and

Textiles, College of Home

Science, G.B. Pant University of

Agriculture and Technology,

Pantnagar, U.S. Nagar

(Uttarakhand) India

Email : alkagoelp@gmail.com
ABSTRACT : Under the present study woven shawls were prepared from pure and blended yarns of merino and mulberry silk waste in (50:50) blend ratios on handloom. 30 arrangements of motifs were made on CAD. These arrangements were evaluated by a panel of experts using a five point ranking proforma for different attributes namely, arrangement of motifs, colour combination, overall aesthetic appearance and suitability for selected articles. As per the ranking the five best designs were selected for the development of woven shawls. The outcome of the study divulges that the cost of the shawls was found reasonable with regards to the work, quality and fibre content of the fabric. The developed products were highly appreciated by the traders as shown by their acceptability (above 80\%) to all developed shawls for different parameters i.e. overall aesthetic appearance of the design, recognition with current fashion trends and suitability of the developed fabrics for shawls. They appreciate the texture, weave, drape, softness and hand of the developed shawls. Traders expressed great scope of this type of silk and wool blended shawls because silk has the greater commercial importance especially in exports.

KEY WORDS: Weaving, Mulberry silk, Merino wool, Blending, CAD, Handloom

- HOW TO CITE THIS PAPER : Goel, Alka and Upadhayay, Hema (2018). Development of handloom shawls from pure and blended yarns of mulberry silk and merino wool. Asian J. Home Sci., 13 (1) : 265-270, DOI: 10.15740/HAS/AJHS/13.1/265-270. Copyright@ 2018: Hind Agri-Horticultural Society. 